\title{
The influence of sorogan method in learning history to increase historical understanding and historical awareness
}

\author{
Muhammad Rijal Fadli ${ }^{1}$, Ajat Sudrajat ${ }^{2}$, Aman $^{3}$, Kian Amboro ${ }^{4}$ \\ 1,2,3 Graduate School, Doctoral Program, Universitas Negeri Yogyakarta, Indonesia \\ ${ }^{4}$ History Education, Universitas Muhammadiyah Metro, Indonesia
}

\section{Article Info \\ Article history: \\ Received Aug 28, 2020 \\ Revised Dec 16, 2020 \\ Accepted Feb 5, 2021 \\ Keywords: \\ Historical awareness Historical learning Sorogan method Understanding history}

\begin{abstract}
The purpose of this study was to examine the influence of the sorogan method in history learning to improve students' historical understanding and historical awareness. The research method used a quasi-experimental nonequivalent control group design, and the sampling technique used a cluster sampling with a sample size of 96 students. Collecting data through observation, interviews, and tests of historical understanding and awareness. Meanwhile, data analysis to determine the effect and differences of the sorogan method to increase understanding and historical awareness using the independent sample t-test and $\mathrm{N}$-gain score test. The results showed that there were a significant influence and difference between the two groups, namely the experimental and control classes based on the results of the independent sample t-test, the hypothesis $\mathrm{H} 0$ was rejected with a significance value of $0.000<0.05$, further strengthened by the results of the $\mathrm{N}$-gain score test which was included in the criteria low and medium. This means that there is an influence and increase from the implementation of the sorogan method on historical understanding and awareness and getting a positive response from teachers and students, because the sorogan method is studentcentered, and the teacher acts as tutorship/mentorship.
\end{abstract}

This is an open access article under the CC BY-SA license.

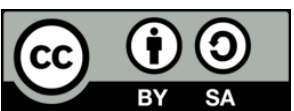

\section{Corresponding Author:}

Muhammad Rijal Fadli

Graduate School, Doctoral Program

Universitas Negeri Yogyakarta

Jl. Colombo No. 1, Yogyakarta Special Region, 55281 Indonesia

Email: muhammadrijal.2020@ student.uny.ac.id

\section{INTRODUCTION}

The flow of globalization in the Industrial Revolution 4.0 era has brought changes to the nation's culture, this has made access to live easier. The impact of globalization has had other contrasting impacts. As a result, it can fade cultural boundaries as a national identity, because creating a young nation is now immersed in global culture and leaving local and national culture aside [1]. The practice of daily life patterns make styles and behavior change with styles outside the Indonesian context, such as Korean cultural styles, and Western cultural styles [2]. This behavior can threaten the values of Pancasila (Indonesian ideology) amidst the emergence of many foreign ideologies that are incompatible with the identity of the Indonesian nation itself.

Fibrianto, et al. research [3] explained that the influence of Korean waves has made them more popular in Indonesia, this is the impact of the globalization flow, which is all digital, accessible through digital. Bagas, et al. [4] showed that most of the younger generation are now lazier in studying or known as creating confusion/lying down. This generation is easy and complaints about motivation and creativity. This 
is what makes one of the impacts of not understanding and being aware of the history of their nation because many foreign cultures have entered so that young people are now free to access the digital world in the era of globalization.

The impact of globalization indirectly gives birth to a process of homogenizing the nation's culture, this causes a shift in the identities of each nation which has its uniqueness and uniqueness. The waning of the national identity is the same as threatening the existence of the national identity [5]. This condition is currently happening to the Indonesian nation, the Indonesian people are unwittingly being carried away by the swift currents of globalization so that the identity and identity of the nation are not felt to be eroded and degraded $[6,7]$. One of the indicators of the Indonesian nation, which has its characteristics, is beginning to be forgotten about its past because no nation in the world has the same national past.

The current problem faced by the Indonesian people is the low understanding and awareness of history, even though like it or not, at least humans must learn from their past or history. This symptom was expressed by Adriaan van Dis [8] that Indonesians generally lack interest in the history of their own country, they prefer the myths and fantasies of nationalism because the level of intellectual awareness of Indonesian intellectuals is still minimal towards the historical awareness of their nation. Furthermore, Latief [9] said that today the behavior of life leads to a pattern of pragmatism which tends to lead to placing use values in every thought and action. This explicitly raises the claim, what is the practical use and benefit of historical awareness. Of course, this question is not wrong, however, it must be answered that historical consciousness is not promising and will not provide practical and material benefits for humans [10]. But it needs to be realized that this does not mean that history has no useful value. History can be used as an experience and encourages national life in the present, present and future.

The current situation and condition of historical awareness are very relevant so it is necessary to maintain the identity of the nation in a globalizing culture in the world. Widja [11] revealed that it is precisely people who have mastered technology, so historical awareness is very much needed because the essence of history is the perspective of time and cultural continuity [12]. In line with Latief [9], the historical awareness of society will be able to keep up with the pace of development of science and technology which seems to be racing wildly, so that development is not solely material but needs spiritual balance [13]. This historical awareness can play a role in strengthening the moral content in the development of a nation.

Historical awareness describes a psychological condition that shows the appreciation of the meaning and essence of the nation's history in the past, present, and future [14, 15]. Historical awareness for the Indonesian people is a very important need for development that cannot be separated from an understanding of Indonesian history, because through an understanding of history it can create a form of awareness about history that can shape life in the present and in the future to be better and more advanced [16, 17].

It is very necessary for everyone to have an understanding of history from an early age to know and understand the meaning of past events so that it can be used as a basis for attitudes in dealing with present realities and to determine the future [18]. It means that history needs to be studied from an early age by every individual either formally or non-formally so that the relationship between individuals in a society or a nation forms an awareness of the importance of history on issues of common life such as; nationalism, national unity, and integrity [19]. Thus, the realization of the ideals of a society or nation is largely determined by the next generation who can understand the history of their nation.

In the Indonesian context, history is part of the way of instilling concepts; nationalism, national unity, and integrity. This concept is what we find in the history of the struggle of the Indonesian nation in fighting for independence. At this level, these ideological concepts constitute a struggle against colonialism and imperialism [20]. This is an understanding of history in terms of holistic experience as a system of past events related to human life in the present and the future, which contains the values and character of the struggles of each nation. Each individual must have an understanding of history in order not to be trapped in the tendency of "presentism", and also not to negate the existence of systematic causality and concepts as the shaping of the present life and future direction of life [21]

The form of efforts that must be made in instilling and increasing historical understanding and awareness is through history learning. Because in history learning not only provides historical knowledge but also aims to awaken students or raise historical awareness so that in the learning process it is necessary to prioritize the values of life, not just memorizing or presenting names, places, events, and numbers [22]. The ideal history learning will be able to shape students' historical understanding because it can provide a tendency to think to reflect the positive values of historical events so that students become wiser and wiser in responding to various life problems.

Effective history learning will provide certain meanings and benefits, especially regarding students' understanding and historical awareness so that instructional design is needed from the history learning it self [23]. Designing history learning is not easy, because it must determine the learning needs of students, besides that, it must also focus on transforming the logical meaning of knowledge into psychological meaning to consider 
students' abilities and conditions so that they run optimally in implementing their learning [24]. More specifically in history learning, the arrangement must also consider the characteristics of historical learning, if the goal is for students to understand and live the values contained in every historical event, then the design made can express these values so that students can understand the young.

To achieve these objectives, this study presents an effective historical learning method to create an atmosphere of efficient learning activities and make students directly involved. Because with the right learning method will greatly affect the success of students. Specifically, the learning method is the sorogan method. This method presents a system, where each student will get a different assignment from the teacher to study certain historical material, and it is presented or explained to the teacher's face to face [25, 26]. With the sorogan method, students have their respective demands and responsibilities for the assignment given by the teacher, the goal is that students can understand the material and absorb the values contained in the material $[27,28]$.

The purpose of this study focuses on the implementation of the sorogan method in history learning to improve students' historical understanding and historical awareness. The sorogan method is not usually used in history learning, because the sorogan method is adopted from learning in the pesantren (Islamic boarding school). The researcher wants to see whether there are differences in the use of historical learning methods in general with this different sorogan method because according to the researcher, the sorogan method is very good when used in history learning to convey material and transfer the value contained in historical material.

\section{RESEARCH METHOD}

The research method used a quantitative approach with a quasi-experimental non-equivalent control group design [29, 30]. This design method is used to determine the effect and differences in the learning methods applied, in determining the population divides into two groups, namely the experimental class group (which is given treatment) and the control class (not given treatment or conventional). Before being given treatment, these two groups must be given a test first, namely the pre-test and post-test, the aim is to know the changes that have occurred between the two groups [31]. The research population of Senior High School in Lampung, Indonesia, namely Senior High School TMI Metro Lampung and Madrasah Aliyah MAN 2 Metro Lampung with a sample of class X students, the number of samples used was 96 with details of 64 experimental classes and 32 control classes. The details can be seen in Table 1 .

Table 1. Details of the research sample

\begin{tabular}{lcccc}
\hline No. & Class group & School & Determination population & Sample size \\
\hline \multirow{2}{*}{ 1. } & \multirow{2}{*}{ Experiment class } & SMA TMI & $\frac{48}{187} \times 126=32.34$ & 32 \\
& & $\frac{48}{187} \times 126=32.34$ & 32 \\
2. & \multirow{2}{*}{ Control class } & MAN 2 & $\frac{47}{187} \times 126=31.66$ & 32 \\
& & Total & & 96 \\
\hline
\end{tabular}

Sampling data using a cluster sampling technique that has been determined by the researcher and made into several groups which will be divided into two groups. In this study, data collection techniques were obtained from observation, interviews, and tests (pre-test and post-test). The data analysis used statistical analysis using independent sample t-test and $\mathrm{N}$-gain scores to determine the effect and difference of the results of the pre-test and post-test scores. However, before testing the effect of the sorogan method using the independent sample t-test, you must conduct a pre-requisite test for data variant analysis to determine whether the data analysis for hypothesis testing can be continued or not. Analysis of the data variants is a test of normality and homogeneity, this test is carried out so that the data from the population is normally distributed and the groups are compared homogeneously, then after that, it can be continued to test the hypothesis analysis.

Analysis of the calculation of the normality test using the Shapiro-Wilk path model with a hypothesis of significance value $\alpha>0.05$. The homogeneity test was carried out using one-way ANOVA analysis using Levene's Test with a significance value of $\alpha>0.05$. The independent sample t-test to determine significant differences in meaning between the two classes of significance was the significance value $\alpha<0.05$, while the $\mathrm{N}$-gain score test was used to determine the increase in students' historical understanding and historical awareness. This data analysis test was assisted by a program SPSS version 22.0. The categorization of the N-gain score can be determined based on the N-gain value. The distribution of categories for the Ngain value can be seen in Table 2 . The value of the increase is calculated by the formula for the $\mathrm{N}$-gain score with the categories [32] as in (1). 


$$
N-\text { Gain }=\frac{(\text { Posttest Score }- \text { Pretest Score })}{(\text { Ideal Score }- \text { Pretest Score })}
$$

Description:

$\mathrm{N}$-gain $=$ Normalized gain

Post test $=$ The final grade of learning

Pre test $=$ Initial value of learning

Ideal score $=$ Maximum (highest) score that can be obtained

Table 2. Distribution of N-gain scores

\begin{tabular}{cc}
\hline N-gain Scores & Criteria \\
\hline $\mathrm{g}>0.7$ & High \\
$0.3 \leq \mathrm{g} \leq 0.7$ & Medium \\
$\mathrm{g}<0.3$ & Low \\
\hline
\end{tabular}

\section{RESULTS AND DISCUSSION}

\subsection{Results}

The results of the research data analysis from the application of the sorogan method were divided into two groups, namely the Experiment class and the Control class. The division of this group is to determine which class is treated in the application of the sorogan method (experimental class) and the control class that does not use the sorogan method (conventional). Besides, the group division aims to facilitate the analysis of the data obtained. The recapitulation of values from the results of data analysis can be seen in the following table.

Table 3 explains that the number of students in the experimental class is 64 and the control class 32 , the total number of samples is 96 . While the average value of the experimental class is pre-test 72.00 and post-test 83.52 , for the control class pre-test 65.06 and post-test 73.22. Based on the average score obtained between the two classes, it has differences, which means that the application of the sorogan method in history learning affects students' understanding and historical awareness.

Table 3. Statistical description of experiment and control class

\begin{tabular}{lccccc}
\hline \multicolumn{5}{c}{ Descriptive statistics } \\
& N & Minimum & Maximum & Mean & Std. deviation \\
\hline Pre-test experiment & 64 & 50 & 89 & 72.00 & 11.878 \\
Post-test experiment & 64 & 55 & 98 & 83.52 & 11.522 \\
Pre-test control & 32 & 45 & 86 & 65.06 & 11.777 \\
Post-test control & 32 & 34 & 89 & 73.22 & 14.914 \\
Valid N (listwise) & 32 & & & & \\
\hline
\end{tabular}

The results of the statistical descriptions of Table 3 then be analyzed in more depth so that the data can be carried out with further analysis or prerequisite tests. Prerequisite testing is needed to determine hypothesis testing whether data analysis can be continued or not. Analysis of data variance requires that data originating from the population must be normally distributed and the groups being compared are homogeneous. Then the analysis of data variance used is the normality and homogeneity test, the normality test uses the Kolmogorov-Smirnov and Shapiro-Wilk pathway model, while the homogeneity test uses the one-way ANOVA pathway model. The results of the recapitulation of the normality and homogeneity tests can be seen in Table 4 and Table 5.

Table 4 and Table 5 show the results obtained from the normality and homogeneity tests that the data variants are normally distributed and homogeneous. The results of the calculation of the normality test of the Shapiro-Wilk model from the pre-test and post-test values of the experimental and control classes obtained values of $0.133,0.110,0.242$, and 0.270 , which means that all values were above 0.05 (significance $\alpha>0.05$ ). While the results of the homogeneity test of all class groups with the one-way ANOVA model were 0.374 meaning that all the values obtained were above 0.05 (significance $\alpha>0.05$ ).

Data variants that are normally distributed and homogeneous, then proceed to the independent sample t-test, to know the difference between two unpaired samples, in addition to knowing whether there is a difference between the sample applying the sorogan method and those that are not or conventional methods. Description of the hypothesis Ha is accepted if the significance value $(\alpha>0.05)$ or $t_{\text {count }}<t_{\text {table }}$ and if $\mathrm{H}_{0}$ is rejected, the significance value $(\alpha<0.05)$ or $\mathrm{t}_{\text {count }}<\mathrm{t}_{\text {table }}$ [33]. Table 6 shows the recapitulation of the independent sample t-test.

The influence of sorogan method in learning history to increase historical ... (Muhammad Rijal Fadli) 
Table 4. Normality test results

\begin{tabular}{llcccccc}
\hline & \multicolumn{4}{c}{ Tests of normality } & \multicolumn{4}{c}{} \\
& \multicolumn{1}{c}{ Class } & \multicolumn{2}{c}{ Kolmogorov-Smirnov ${ }^{\mathrm{a}}$} & \multicolumn{3}{c}{ Shapiro-Wilk } \\
& & Statistic & df & Sig. & Statistic & df & Sig. \\
\hline \multirow{2}{*}{ Result of historical } & Pre-test experiment & .119 & 64 & .024 & .971 & 64 & .133 \\
understanding and & Post-test experiment & .106 & 64 & .071 & .949 & 64 & .110 \\
awareness & Pre-test control & .105 & 32 & $.200^{*}$ & .958 & 32 & .242 \\
& Post-test control & .121 & 32 & $.200^{*}$ & .960 & 32 & .270 \\
\hline
\end{tabular}

Table 5. Homogeneity test results

\begin{tabular}{llcccc}
\hline & \multicolumn{2}{c}{ Test of Homogeneity of Variance } & & \\
& & Levene statistic & df1 & df2 & Sig. \\
\hline \multirow{2}{*}{$\begin{array}{l}\text { Result of historical } \\
\text { understanding and }\end{array}$} & Based on mean & .797 & 1 & 94 & .374 \\
awareness & Based on median & .675 & 1 & 94 & .413 \\
& Based on median and with adjusted df & .675 & 1 & 93.675 & .413 \\
& Based on trimmed mean & .690 & 1 & 94 & .408 \\
\hline
\end{tabular}

Table 6. Independent-sample t-test results

\begin{tabular}{|c|c|c|c|c|c|c|c|c|c|}
\hline \multirow{4}{*}{$\begin{array}{c}\text { Result of historical } \\
\text { understanding and awareness }\end{array}$} & \multicolumn{7}{|c|}{ Independent samples test } & & \\
\hline & \multicolumn{3}{|c|}{$\begin{array}{l}\text { Levene's test } \\
\text { for equality of } \\
\text { variances }\end{array}$} & \multicolumn{4}{|c|}{ t-test for equality of means } & & \\
\hline & \multirow[t]{2}{*}{$\mathrm{F}$} & \multirow[t]{2}{*}{ Sig. } & \multirow[t]{2}{*}{$\mathrm{t}$} & \multirow[t]{2}{*}{ df } & \multirow{2}{*}{$\begin{array}{c}\text { Sig. } \\
\text { (2-tailed) }\end{array}$} & \multirow{2}{*}{$\begin{array}{c}\text { Mean } \\
\text { difference }\end{array}$} & \multirow{2}{*}{$\begin{array}{l}\text { Std. error } \\
\text { difference }\end{array}$} & \multicolumn{2}{|c|}{$\begin{array}{l}95 \% \text { confidence interval of } \\
\text { the difference }\end{array}$} \\
\hline & & & & & & & & Lower & Upper \\
\hline Equal variances assumed & .797 & .374 & 4.200 & 94 & .000 & 7.25000 & 1.72634 & 3.82231 & 10.67769 \\
\hline
\end{tabular}

Based on the output Table 6, it shows that the independent sample t-test results obtained with the Sig. (2-tailed) of $0.000<0.05$, so that $\mathrm{H}_{\mathrm{a}}$ is accepted. This means that there is a difference in the average score of students' understanding and historical awareness between the sorogan method and the conventional method. This was confirmed using the $\mathrm{N}$-gain score test which can be seen in the Table 7 .

Table 7. N-gain score test results

\begin{tabular}{ccc}
\hline Class & N-gain score & Criteria \\
\hline Experiment 1 & 0.4 & Medium \\
Experiment 2 & 0.4 & Medium \\
Control & 0.2 & Low \\
\hline
\end{tabular}

Based on Table 7, it shows that the $\mathrm{N}$-gain value for experimental classes 1 and 2 is $0.4 \leq 0.7$ which is included in the medium criteria. While the gain from control class $0.2 \leq 0.7$ is classified as low criteria. It means that from the calculation of the $\mathrm{N}$-gain score test there is a significant increase with the mean score of the pre-test experimental class 1 is 76.03 and the post-test is 85.31 , experiment 2 pretest 70.71 and post-test 81.75. The mean value of the pre-test score of the control class was 70.21 and the post-test 76.28.

Thus, the results of the $\mathrm{N}$-gain score test for the two groups (experimental class and control class) were different and improved. It is known from the results of the $\mathrm{N}$-gain score test, where the experimental class obtained an $\mathrm{N}$-gain score of 0.4 with moderate criteria, and the control class only obtained an $\mathrm{N}$-gain score of 0.2 which is included in the low criteria. This means that the average $\mathrm{N}$-gain score of the experimental class is greater and increases compared to the control class. These results indicate that the implementation of the sorogan method in learning history has an influence and can increase understanding and awareness of history for students.

\subsection{Discussion}

The results of the analysis show that the sorogan method in learning is more influential and efficient for increasing students' historical understanding and historical awareness compared to conventional learning methods. This sorogan method is adopted from the pesantren circles where a Santri (student) hands a book to the teacher or Kiai to be read or presented in front of the Kiai [33,34]. Presentation with the sorogan method can be said to be the transfer of values as a process of delivery of culture in Islamic boarding schools, 
commonly called tutorship/mentorship $[35,36]$. This sorogan method is considered important because it can help students develop intellectual abilities and skills individually, so that the focus can be on students who are guided by their teachers [37].

The sorogan method, if transformed in the world of formal education, will be very efficient and effective. Technically the sorogan method is applied in formal learning starting with: 1) Students facing the teacher with predetermined material; 2) The teacher provides an explanation regarding the material that has been given to students; 3) Students must pay attention to the teacher when explaining carefully because; 4) Students must follow or imitate the material taught by the teacher. With this technique, learning will be very effective and efficient so that the determined competency objectives can be achieved optimally.

The sorogan method can be said to be a modern learning method because this method can build good interaction between teachers and students so that the material being taught is easy and quickly understood by students. With the sorogan method, both teachers and students both make thorough preparations in studying the material, from here the teacher will be able to find out the character development or understanding of students, so this sorogan method is very efficient when applied in history learning.

In learning history, understanding and historical awareness is the most important part of achieving learning objectives, so that these two parts must be actualized by students so that the values contained in historical events can be reflected into positive values in the times [38]. Purwanta [39] explains that historical understanding is the ability to listen to and understand historical stories to identify basic elements of narrative or story structures that can be used as a basis for attitudes and policies in facing life. Meanwhile, Susanto [40] explains that historical awareness is the intellectual and mental ability to understand, interpret, and make reflective use of historical experience/historical understanding to critically respond to various phenomena faced in the present and future. Thus, understanding and historical awareness are some of the most important parts for students in helping and sharpening national identities [41]. Morally, students will also be moved to encourage progress that leads to the development of the common good for the nation [42]. Historical understanding and awareness can make students enforce social harmony or cohesion. Through these two parts, students will be wise about the values of past society and various social agreements, so that students will become strong actors to direct today's society in solving problems comprehensively.

History learning has the aim of forming good citizens, making students aware of themselves and their environment, and providing a historical perspective. With history, students can learn what cannot be seen, and introduce us to visions that we have not known since we were born [43, 44]. History learning is carried out to achieve the target results of the learning process itself, which includes academic skills, historical understanding, historical consciousness, and nationalism, of course, based on the results of the quality of the learning process that has been adequate, everything can be achieved [45]. So, it is very necessary to choose a history learning method so that the desired goal is achieved, there have been many proven methods and models of history learning to be used and to increase students' understanding of history and awareness [46]. However, this study applies the sorogan method which is very rare in the world of formal education, because the sorogan method is only used in the world of pesantren education.

Research from Wakit [47] suggests that the sorogan method is very effective and efficient when applied to learning in the world of formal education or outside the Islamic boarding school because with this sorogan method students can develop their respective abilities guided by the teacher. Rinangsih, et al. [48] also argue that this sorogan method has a good effect because this method can provide understanding and skills to students. After all, learning is student-centered so students must be responsible for the material provided by the teacher [49]. In line with Saputri, et al. [50] the sorogan method does have its impact on improving students' understanding ability in absorbing the material being taught. In this study, he agrees with this research, because by applying the sorogan method it can affect the academic ability, understanding, and historical awareness of students, based on the results of the data analysis that has been done above.

The novelty of this research focuses on the application of the Sorogan method which is implemented in history learning. This is because the sorogan method has been adopted from Islamic boarding schools in Indonesia which is not usually applied in historical learning, moreover, the sorogan method is only known among pesantren [51]. The application of the sorogan method in learning history is very influential in increasing students' understanding of history and awareness based on the results of the research that has been done. The sorogan method applied in history learning greatly influences students to increase understanding and historical awareness because sorogan method has its concept that can build teacher-student interaction relationships so that teachers can control and guide the development of individual students. With this method, the teacher will be greatly helped to emphasize the objectives of learning history optimally. 


\section{CONCLUSION}

The implementation of the sorogan method in history learning has a significant effect on improving students' historical understanding and historical awareness, based on the results of data analysis from the independent sample t-test which shows that the scores obtained from the pre-test and post-test scores of the experimental and control classes there is a significant difference with the acquisition of the Sig. (2-tailed) of $0.000>0.05$. It means that there is a difference between the experimental class (which uses the sorogan method) and the control class (conventional) so that the application of the sorogan method is indeed very influential in learning history and can also increase students' understanding and historical awareness. The statement is based on the results of the $\mathrm{N}$-gain score test with the acquisition of an $\mathrm{N}$-gain score for the experimental class 0.4 and the control class 0.2 . This research has implications both practically and theoretically, practically the school or teacher can consider being able to apply the sorogan method to establish good relationships or interactions between teachers and students for educational purposes so that students' intellectual abilities and character can be maximally formed according to demands of the times. This research justified the application of the sorogan method to influence the material taught to students, so that it can generate a good response to students so that they continue to learn history. This research can also be used as a source of theory or a reference that is used as supporting material in other research.

\section{ACKNOWLEDGEMENTS}

Many thanks to my parents who have given their support and blessing to continue their doctoral studies at their own expense. Thank you to the students of class X Senior High School Lampung, who have provided assistance and contribution as respondents in this study. Thank you also to the alma mater of Yogyakarta State University who has provided a lot of knowledge and contributed to work.

\section{REFERENCES}

[1] W. Ryoo, "Globalization, or the logic of cultural hybridization: The case of the Korean wave," Asian Journal of Communication, vol. 19, no. 2, pp. 137-151, 2009.

[2] Y. L. Lee, M. Jung, R. J. Nathan, and J.-E. Chung, "Cross-National Study on the Perception of the Korean Wave and Cultural Hybridity in Indonesia and Malaysia Using Discourse on Social Media," Sustainability, vol. 12, no. 15 , pp. 1-33, 2020.

[3] A. S. Fibrianto, et al., "Analysis of Globalization Phenomena: Forms of K-Pop Cultural Fanaticism among Students (Case Study of Sociology Student at Universitas Negeri Malang)," in International Conference on Social Studies and Environmental Issues (ICOSSEI 2019), 2020, vol. 404, pp. 319-324.

[4] B. P. Wibowo, T. Wulandari, and J. Setiawan, "Relationship Between the Understanding of Indonesian History and The Nationalism Attitude of State Senior High School Students," International Journal of Education and Social Science Research, vol. 1, no. 3, pp. 21-29, 2017.

[5] L. Agung, "The Role of Social Studies and History Learning in Junior High School in Strengthening the Students Character," Paramita Historical Studies Journal, vol. 25, no. 2, pp. 238-246, 2015.

[6] M. Maskun, R. A. Pratama, and S. Sumargono, "Implementation of Character Education in Historical Learning in the Industrial Revolution Era 4.0," International Journal of Multicultural and Multireligious Understanding, vol. 6, no. 6, pp. 487-496, 2019.

[7] A. R. Haniah, Aman, and R. Setiawan, "Integration of Strengthening of Character Education and Higher Order Thinking Skills in History Learning," Journal of Education and Learning (EduLearn), vol. 14, no. 2, pp. 183-190, 2020.

[8] K. Amboro, "Building Awareness Begins with Understanding: The Relationship between Historical Understanding and Historical Awareness of Students of the History Education Study Program, FKIP Muhammadiyah University Metro," Historia, vol. 3, no. 2, pp. 109-117, 2015.

[9] J. A. Latief, Humans, Philosophy, and History (in Bahasa). Jakarta: Bumi Aksara, 2008.

[10] U. Azizah, Djono, and A. A. Musaddad, "The Integration of Lafran Pane Thought in Material for Teaching History in Indonesian Student," VNU Journal of Science: Education Research, vol. 35, no. 2, pp. 35-40, 2019.

[11] I. G. Widja, Towards a New Face of Historical Education (in Bahasa). Lappera Pustaka Utama, 2003.

[12] P. Seixas, "Collective Memory, History Education, and Historical Consciousness," Historically Speaking, vol. 7, no. 2, pp. 17-19, 2005.

[13] Sariyatun, H. Joebagio, and B. Sumardjoko, "Proliferation of Democratic Education in Indonesia: The Influence Measurement of Tolerance, Multiculturalism, and Historical Awareness on the Democratic Attitude," The New Educational Review, vol. 25, no. 2, pp. 112-125, 2018.

[14] J. J. S. Cakranegara, "Building Critical and Integrative Historical Awareness for Advanced Indonesia," Journal Pertahanan Bela Negara, vol. 10, no. 1, pp. 1-18, 2020.

[15] L. Del P. E. Rincón, "Pensar la ensenanza de la historia reciente desde la conciencia historica/Thoughts on teaching recent history with historical awareness Pensando no ensino da historia recente a partir da consciencia historica," Cuidad paz-ando, vol. 12, no. 3, pp. 220-231, 2019. 
[16] Y. Rusvitaningrum, L. Agung, and S. Sudiyanto, "Strengthening Students' Historical Awareness in History Learning in High School Through Inquiry Method," International Journal of Multicultural and Multireligious Understanding, vol. 5, no. 5, pp. 249-255, 2018.

[17] U. A. Jannah and T. A. Ahmad, "Historical Awareness of Class XI Students Against the Exemplary Values of K.H Ahmad Dahlan at SMA Muhammadiyah 1 Semarang," Indonesian Journal of History Education, vol. 7, no. 2, pp. 135-145, 2019.

[18] O. C. Ferrell, J. F. Hair, G. W. Marshall, and R. D. Tamilia, "Understanding the History of Marketing Education to Improve Classroom Instruction,” Marketing Education Review, vol. 25, no. 2, pp. 159-175, 2015.

[19] A. H. Nasution and F. Tanjung, Curriculum and History Learning (in Bahasa). Medan: Yayasan Kita Menulis, 2020.

[20] H. Susanto, "Understanding of Regional History and Perception of Cultural Diversity in Developing Nationalism," Historia Jurnal Pendidik dan Peneliti Sejarah, vol. 14, no. 1, pp. 91-112, 2013.

[21] S. Wineburg, "Historical thinking and other unnatural acts," Phi Delta Kappa International, vol. 92, no. 4, pp. 81-94, 2010.

[22] S. Wineburg, Historical Thinking and Other Unnatural Acts: Charting the Future of Teaching the Past. Philadelphia: Temple University Press, 2002.

[23] S. K. Kochhar, Teaching of History. Jakarta: Grasindo, 2008.

[24] M. R. Fadli and A. Sudrajat, "History Learning Module Based on Islamic Values on K.H. Hasyim Asy'ari's Jihad Resolution Material," Tadris: Jurnal Keguruan dan Ilmu Tarbiyah, vol. 5, no. 1, pp. 65-75, 2020.

[25] S. Sauri, N. Nursyamsiah, and Y. Nurbayan, "A critique of local wisdom values in Indonesia's pesantren," Pertanika Journal of Social Sciences \& Humanities, vol. 26, no. T, pp. 37-50, 2018.

[26] M. Qomar, Pesantren: From Methodological Transformation to Institutional Democratization. Jakarta: Erlangga, 2010.

[27] R. Rinaningsih, A. Kadarohman, and H. Firman, "The Sorogan-Bandongan Model as Active Learning Model in Indonesia," in Proceedings of the National Seminar on Chemistry 2019 (SNK-19), 2020, vol. 1, pp. 229-231.

[28] Abdurrahman, "Genealogy of the Sorogan Method (Historical Research of Learning Methods in the Tradition of Pesantren)," Jurnal Studi Pesantren, vol. 1, no. 01, pp. 1-14, 2020.

[29] Sugiyono, Educational Research Methods: (Quantitative, Qualitative and $R \& D$ Approaches) (in Bahasa). Bandung: Alfabeta, 2016.

[30] T. Teo, Handbook of quantitative methods for educational research. Rotterdam: Sense Publishers, 2013

[31] M. L. Maciejewski, "Quasi-experimental design,” Biostatistics \& Epidemiology, vol. 4, no. 1, pp. 38-47, 2020.

[32] R. R. Hake, "Analyzing change/gain scores," Unpublished, 1999. [Online]. Available: https://www1.physics.indiana.edu/ sdi/AnalyzingChange-Gain.pdf.

[33] T. K. Kim, "T test as a parametric statistic," Korean Journal of Anesthesiology, vol. 68, no. 6, pp. 540-552, 2015.

[34] S. Ma'arif, "Education as a foundation of humanity: Learning from the pedagogy of pesantren in Indonesia," Journal of Social Studies Education Research, vol. 9, no. 2, pp. 104-123, 2018.

[35] S. Pulungan, History of Islamic Education (in bahasa). Jakarta: Kencana, 2019.

[36] Z. Dhofier, Pesantren Tradition the Study of Kyai's Life View (in Bahasa). Jakarta: LP3ES, 1994.

[37] N. Khakim, "Sorogan became a Learning Model at the Darul Muttaqin Bantargebang Islamic Boarding School," Jurnal Penelitian Ilmu Pendidikan, vol. 9, no. 2, pp. 1-8, 2018.

[38] A. Aman, "Development of an Evaluation Model for the History Learning Program in Senior High School," Jurnal Penelitian dan Evaluasi Pendidikan, vol. 16, no. 2, pp. 437-456, 2013.

[39] H. Purwanta, The Rights of Historical Education (in Bahasa). Surakarta: UNS Press and CHERS, 2019.

[40] H. Susanto, Around Learning History: Issues, Ideas and Learning Strategies. Yogyakarta: Aswaja Pressindo, 2015.

[41] J. Setiawan, Aman, and T. Wulandari, "Understanding Indonesian history, interest in learning history and national insight with nationalism attitude," International Journal of Evaluation and Research in Education (IJERE), vol. 9, no. 2, pp. 364-373, 2020.

[42] S. H. Abdullah, Historical Education of Thought, Understanding and Empathy. Penang: USM Press (University Sains Malaysia), 2019.

[43] K. Yilmaz, "A Vision of history teaching and learning: thoughts on history education in secondary schools," The High School Journal, vol. 92, no. 2, pp. 37-46, 2008.

[44] M. R. Fadli, A. Sudrajat, Z. Zulkarnain, A. Aman, R. Setiawan, and K. Amboro, "The effectiveness of E-Module learning history inquiry model to grow student historical thinking skills material event proclamation of Independence," International Journal of Advanced Science and Technology, vol. 29, no. 08, pp. 1288-1295, 2020.

[45] P. Hillis, "The position of history education in Scottish schools," Curriculum Journal, vol. 21, no. 2, pp. 141-159, 2010.

[46] E. Suparjan, Historical Education to Form National Character (in Bahasa). Yogyakarta: Deepulish Publisher, 2019.

[47] A. Wakit, "The Effectiveness of the Peer Tutor Assisted Sorogan Method on Understanding Mathematical Concepts," JES-MAT (Jurnal Edukasi dan Sains Matematika), vol. 2, no. 1, pp. 1-12, 2016.

[48] Rinaningsih, A. Kadarohman, H. Firman, and S. Sutoyo, "Profile of students' learning styles in SoroganBandongan organic chemistry lecture," Journal of Physics: Conference Series, vol. 1013, no. 1, pp. 1-6, 2018.

[49] L. Sulistyo and P. Priyo, "Implementation of Learning Mathematics with the Learning CD Assisted Sorogan Model," DISPROTEK, vol. 5, no. 2, pp. 28-43, 2014.

[50] D. Saputri, H. Budiman, R. Wahyu, and Y. Putra, "The Impact of Mathematical Learning based on Sorogan Methods Assisted by Peer Tutors against Students' Mathematical-Concepts Understanding," Journal of Mathematical Pedagogy (JoMP), vol. 1, no. 1, pp. 9-17, 2019.

[51] M. N. S. F. Sakti, Santriducation 4.0. Jakarta: PT Elex Media Komputindo, 2020. 